\title{
Are extrovert people more satisfied with life? Case study
}

\author{
Elena-Ramona Richițeanu-Năstase ${ }^{1}$, Camelia Stăiculescu ${ }^{2}$ \\ 1 The Bucharest University of Economic Studies, Bucharest, Romania, ramona_richiteanu@yahoo.com \\ 2 The Bucharest University of Economic Studies, Bucharest, Romania, camistaiculescu@ yahoo.com
}

\begin{abstract}
Psychological and psycho-social research have studied the strong dependence between subjective wellbeing and personality. Research findings have shown that an optimistic, extrovert person has a higher level of life satisfaction. In this paper, we shall try to present the research results of a study made on 150 students enrolled at The Bucharest University of Economic Studies. We have studied if this correlation between extraversion and the level of life satisfaction applies to our sample. We have used two well established and known instruments: Life Satisfaction Inventory (Diener, 2006) and the E-Scale of EPQ (Eysenck Personality Questionnaire). Results show that the correlation is maintained, a more extravert person has a higher level of satisfaction with life. Our research also opens some questions regarding the possibility of training this personality trait and proposes a personal development and coaching program.
\end{abstract}

Keywords. Extraversion, satisfaction with life, personal development, wellbeing.

\section{Introduction}

The theme of happiness, the subjective wellbeing is a actual, very important theme of study for many research studies. That is not only because striving to achieve happiness is the purpose of any human, but because the subjective wellbeing is studied as synonymous with mental health (Diener, Lukas, Oishi, 2002) and reveals the protective role it has against stressor agents and the ability to prevent depression.

Many psychological and psycho-social research have studied the strong dependence between subjective wellbeing and personality. Research findings have shown that an optimistic, extrovert person has a higher level of life satisfaction.

Also, studies show that genetic factors have a great influence in which people evaluate their life (Lykken and Tellegen, 1996). They state that $80 \%$ percent of the variance of subjective wellbeing is explained through genetic factors. Costa and McCrae (1980) stated that extraversion and happiness are correlated. M. Argyle and L. Lu (1990) determined that Eysenck extraversion scale and Oxford Happiness Inventory are correlated. Argyle and L. Lu also affirm that half of the grater happiness of the extraverts can be explain by their greater participation in social activities. We think that the participation to social activities is the effect, but not the cause of the happiness of the extraverts.

Eysenk, Eavesand Martin (1989) state that extraversion and introversion is explained through genetic factors and extraverts have a lower cortical arousal than introverts and they seek arousal in social activity. But this does not explain why they seek positive encounters? Maybe the explanation of positive social encounters of the extraverts can be explain by another study. Gray (1972, apud M. Argyle and L. Lu, 1990) state that positive orientation of 
extraverts is related to the difference in brain structure, extraverts magnify rewords while introverts magnify punishments.

Whichever the cause of extraversion, we think is important to identify if a correlation exists, and if it does, the practical importance of it...can it be developed? Can we have more extravert, opened, happy, mentally heathy people?

In this paper, we shall present the results of our study focused on identifying if a correlation between extraversion and the level of life satisfaction applies to our sample.

\section{Research Methods}

\subsection{Methodology}

The research is conducted on 150 students from The Bucharest University of Economic Studies, Romania enrolled in bachelor, master and doctoral programs. (42 male students $28 \%$ and 108 female students $-72 \%$ ). Most of the respondents were enrolled in master programs $(60,7 \%)$.

In our research we have used two well established and known instruments: Life Satisfaction Inventory (Diener, 2006) and the E-Scale of EPQ (Eysenck Personality Questionnaire).

Life Satisfaction Inventory was proposed by Ed Diener in 1985. We used the 2006 form of the instrument. The instrument has 5 items with a 7 Likert scale. The scores range from 5 to 35 . The $30-35$ score is a very high score and means a highly satisfied individual, 25- 29 is a high score and means a satisfied individual, $20-24$ is an average score, $15-19$ is a slightly below average in life satisfaction, $10-14$ dissatisfied and 5-9 Extremely Dissatisfied. The Satisfaction with Life Scale (SWLS) was developed to assess satisfaction with the respondent's life as a whole.

Eysenck Personality Questionnaire (EPQ) is a questionnaire that assess the personality traits of a person in terms of extraversion/introversion, neuroticism/stability and sincerity. It consists of 57 statements that the respondent answers with yes and no. At the beginning of our study, we used only those items that refer to extraversion/introversion (E-scale), but very interesting results were obtain using also the neuroticism scale.

We also used items regarding identification elements - gender, age, the level of education, working status as to explore if they affect the level of satisfaction with life and extraversion.

To obtain the necessary data to our research we integrated the instruments in only one instrument using Google forms application and we distributed, collected and analyzed the obtained data using SPSS.

\subsection{Findings}

The results show that the correlation is maintained, that E-Scale of EPQ can be used as an instrument to assess the level of satisfaction with life, and that a more extravert person has a higher level of satisfaction with life (see Table 01.Correlations).

Although in the beginning we had no intention of identifying a correlation between life satisfaction and the level of neuroticism, but it exists and is negatively correlated $\left(-, 275^{* *}\right.$. This means that a balanced person with a low level of neuroticism has a greater level of 
satisfaction with life. Exploring this, we asked whether the socially driven idea that sanguine temperament would be the best, research data shows that the sanguine (balanced, with low level of neuroticism extraverted) has a greater life satisfaction than other temperaments. From our group of participants, $58 \%$ are sanguine (87 respondents).

Table 01. Correlations

\begin{tabular}{|c|c|c|c|c|c|c|c|c|}
\hline & & $\begin{array}{l}\text { Level of } \\
\text { satisfaction }\end{array}$ & $\begin{array}{l}\text { Extraversi } \\
\text { on }\end{array}$ & Age & Gender & $\begin{array}{l}\text { Level of } \\
\text { education }\end{array}$ & $\begin{array}{l}\text { Working } \\
\text { status }\end{array}$ & Neuroticism \\
\hline \multirow{3}{*}{$\begin{array}{l}\text { Level of } \\
\text { satisfaction }\end{array}$} & $\begin{array}{l}\text { Pearson } \\
\text { Correlation }\end{array}$ & 1 &, $284^{* *}$ &,- 093 & , 124 &, 142 &, $271^{* *}$ &,$- 275^{* *}$ \\
\hline & $\begin{array}{l}\text { Sig. } \\
\text { tailed })\end{array}$ & & ,000 & ,258 & ,131 & ,083 & ,001 & ,001 \\
\hline & $\mathrm{N}$ & 150 & 150 & 150 & 150 & 150 & 150 & 150 \\
\hline \multirow{3}{*}{$\begin{array}{l}\text { Extraversio } \\
\mathrm{n}\end{array}$} & $\begin{array}{l}\text { Pearson } \\
\text { Correlation }\end{array}$ &, $284^{* *}$ & 1 & ,118 &,- 140 &, $260^{* *}$ &, $169^{*}$ &,$- 291^{* *}$ \\
\hline & $\begin{array}{l}\text { Sig. } \\
\text { tailed) }\end{array}$ & ,000 & & , 151 & ,087 & ,001 & ,039 & ,000 \\
\hline & $\mathrm{N}$ & 150 & 150 & 150 & 150 & 150 & 150 & 150 \\
\hline \multirow{3}{*}{ Age } & $\begin{array}{l}\text { Pearson } \\
\text { Correlation } \\
\end{array}$ &,- 093 & , 118 & 1 &,$- 350^{* *}$ &, $185^{*}$ & ,095 &,$- 165^{*}$ \\
\hline & $\begin{array}{l}\text { Sig. } \\
\text { tailed) }\end{array}$ & ,258 & , 151 & & ,000 & ,023 & ,248 & ,044 \\
\hline & $\mathrm{N}$ & 150 & 150 & 150 & 150 & 150 & 150 & 150 \\
\hline \multirow{3}{*}{ Gender } & $\begin{array}{l}\text { Pearson } \\
\text { Correlation }\end{array}$ & , 124 &,- 140 &,$- 350^{* * *}$ & 1 &,$- 208^{*}$ &,- 059 &, $170^{*}$ \\
\hline & $\begin{array}{l}\text { Sig. } \\
\text { tailed) }\end{array}$ &, 131 & ,087 & ,000 & & ,011 & ,470 & ,038 \\
\hline & $\mathrm{N}$ & 150 & 150 & 150 & 150 & 150 & 150 & 150 \\
\hline \multirow{3}{*}{$\begin{array}{l}\text { Level of } \\
\text { education }\end{array}$} & $\begin{array}{l}\text { Pearson } \\
\text { Correlation }\end{array}$ & , 142 &, $260^{* *}$ &, $185^{*}$ &,$- 208^{*}$ & 1 & , 140 &,$- 282^{* *}$ \\
\hline & $\begin{array}{l}\text { Sig. } \\
\text { tailed) }\end{array}$ & ,083 & ,001 & ,023 & ,011 & & ,088 & ,000 \\
\hline & $\mathrm{N}$ & 150 & 150 & 150 & 150 & 150 & 150 & 150 \\
\hline \multirow{3}{*}{$\begin{array}{l}\text { Working } \\
\text { status }\end{array}$} & $\begin{array}{l}\text { Pearson } \\
\text { Correlation }\end{array}$ &, $271^{* *}$ &, $169^{*}$ & ,095 &,- 059 &, 140 & 1 &,- 034 \\
\hline & $\begin{array}{l}\text { Sig. } \\
\text { tailed) }\end{array}$ & ,001 & ,039 & ,248 & ,470 & ,088 & & ,681 \\
\hline & $\mathrm{N}$ & 150 & 150 & 150 & 150 & 150 & 150 & 150 \\
\hline \multirow{3}{*}{ Neuroticism } & $\begin{array}{l}\text { Pearson } \\
\text { Correlation }\end{array}$ &,$- 275^{* * *}$ &,$- 291^{* *}$ &,$- 165^{*}$ &, $170^{*}$ &,$- 282^{* *}$ &,- 034 & 1 \\
\hline & $\begin{array}{l}\text { Sig. } \\
\text { tailed) }\end{array}$ & ,001 &, 000 & ,044 & ,038 & ,000 & ,681 & \\
\hline & $\mathrm{N}$ & 150 & 150 & 150 & 150 & 150 & 150 & 150 \\
\hline
\end{tabular}

Another important result of our study reveal that, the level of satisfaction is also dependent on the status on the labor market. The employed participants have a higher level of satisfaction (correlation is significant at the 0.01 level).

The level of extraversion is higher among students who complete a doctoral program and full time employees. So extraversion is dependent on the level of education. This aspect contradicts to some extent the idea that extraversion is entirely genetic and can change to a small extent. Research data reveals that exposure to broad-based educational experiences, including work experiences, changes the individual, and compels him to adopt attitudes, to form an open, adaptable character, thus overcoming innate traits. We cannot ask ourselves ... 
does the scale of extraversion measure an innate or acquired trait?

Future studies must reveal if the level of satisfaction depends on extraversion as a genetic factor or does extraversion refers only to sociability, an attitude that is dependent on social and educational factors.

Another interesting result of the research reveals that the level of neuroticism is negatively correlated with age. The older we are the less patient and flexible we become. Also, our study show that women are more neurotic than man, but the more educated they are the less neurotic they become.

\section{Conclusion and recommendations}

The results of our study show that extraversion and neuroticism are predictors of the level of satisfaction with life and that higher level of extraversion can be found at students enrolled in higher level of education.

Our research opens some questions regarding the possibility of training these personality traits: extraversion and neuroticism. Our research show that as we offer more educational experiences, the student become more opened, more extravert and less neurotic. Of course not all students will attend a doctoral program, but the university can propose workshops and personal development programs aimed to increase openness, sociability and lower the neuroticism of students.

As a suggestion, we propose a personal development and coaching program for counselling students.

Students counseling is an intensive process of providing psycho-pedagogical assistance to students. The role of counseling is proactive, which means that its objectives are: prevention of personal and educational crisis situations and personal, educational and social development. The workshop is designed to follow the stages of counselling: definition of problem, expressing feelings, clarification of the problem, finding alternatives and establishing a proper plan to face the problem.

In every stage, we think that a very important role it plays the relationship established between the counsellor and participants. This relationship has to be an opened, positive, based on trust and nonjudgmental.

For the first stage we propose using two assessment tools: Life Satisfaction Inventory and EPQ (Eysenck Personality Questionnaire). After scoring and interpretation, participants are asked to express their feelings and thoughts about the scores obtained (agree or disagree, how they feel about the scores, if they want to change something about themselves). The counsellor offers as a positive encouragement the results of some studies that show the correlation between life satisfaction, extraversion and neuroticism.

To better clarify their problem, we propose an exercise following „Johari window"1 model of personal development. In 15 minutes, in pairs, they will try to find out more about their partner (qualities, defects, a recent personal success, a secret). They will exchange roles and in the end characterize their partner in a few words. The idea here is that they understand how they can become more opened, more extravert and feel better about themselves regarding the defects they may have. At the end of the exercise the counselor will present the "Johari window" and will emphasize that in order to develop their blind self, they'll have to ask for feedback more, to develop their hidden self, they'll have to reveal themselves more and to develop their unknown self they'll have to say yes to new situations for which they

\footnotetext{
${ }^{1}$ See https://www.businessballs.com/self-awareness/johari-window-model-and-free-diagrams-68/
} 
haven't developed a learnt behavior. The workshop ends with an individual exercise of planning: every participant has to identify an activity he/she would have wanted to try and didn't and plan simple steps to introduce it to his/hers everyday life. The purpose of the exercise is to identify simple changing actions that can have an effect on extraversion and neuroticism.

We think this workshop will have positive results and can stand as a reference for future research on satisfaction and effects it has on participants.

The results of the study and the workshop proposed can be applied to other categories and levels of education. It will be interesting to see if the same correlation and positive results are maintained.

In conclusion, we think that our study shows that extrovert people are happier, but also that this personality component can be changed and learnt. The workshop proposed is just a glimpse of a counselling program that can be done on this theme. We think that is important for the university, through counselling centers to develop such counselling programs and workshops for happier, more adapt and sociable students.

\section{References}

Costa, P. T., \& McCrae, R. R. (1980). Influence of extraversion and neuroticism on subjective well-being: happy and unhappy people. Journal of personality and social psychology, 38(4), 668.

Diener, E., Emmons, R. A., Larsen, R. J., \& Griffin, S. (1985). The Satisfaction with Life Scale. Journal of Personality Assessment, 49, 71-75

Diener, E., Suh, E., \& Oishi, S. (1997). Recent findings on subjective well-being. Indian Journal of Clinical Psychology, 24, 25-41

Diener, E., Oishi, S., \& Lucas, R. E. (2003). Personality, culture, and subjective well-being: Emotional and cognitive evaluations of life. Annual review of psychology, 54(1), 403-425.

Heath, A. C., Eaves, L. J., \& Martin, N. G. (1989). The genetic structure of personality III. Multivariate genetic item analysis of the EPQ scales. Personality and Individual Differences, 10(8), 877-888.

Lykken, D., \& Tellegen, A. (1996). Happiness is a stochastic phenomenon. Psychological Science, 7(3), 186189. 